Vol. 1, Issue No. 2, July-Dec 2021, 1-23

https://doi.org/10.53034/Transcript.2021.v01.n02.001

\title{
Writing the Self: A Study on Buchi Emecheta's Autobiographical Novel Second Class Citizen
}

\section{Arunima Borah}

https://orcid.org/0000-0001-6181-5121

Jorhat Kendriya Mahavidyalaya, Jorhat, Assam

\begin{abstract}
Life-writing, according to Sidonie Smith and Julia Watson, is a general term for the writing of diverse kinds that takes life as its subject. Such writing can be biographical, novelistic, historical, or an explicit self-reference to the writer. As autobiographies, as well as autobiographical novels, can be considered as self-referential modes of writing, a notion of the terms in which the subject preconceives himself/herself becomes pervasive for understanding autobiographies as well as autobiographical novels. Susan Stanford Friedman, in her essay "Women's Autobiographical Selves: Theory and Practice" (1988) opens a critique of a seminal essay by Georges Gusdorf where he states that the cultural precondition for autobiography is a pervasive concept of individualism, a "conscious awareness of the singularity of each individual life" (Qtd in Friedman 72). Friedman argues that the individualistic concept of the autobiographical self that pervades Gusdorf's work raises serious problems for critics who recognise that the "self, self-creation, and self-consciousness are profoundly different for women, minorities, and many non-western peoples" (Friedman 73). While taking into account the differences in socialization in the construction of male and female gender identity, Friedman refers to Regina Blackburn in her "In Search of the Black Female Self" and says that the "black women autobiographers use the genre to redefine 'the black female self in black terms from a black perspective" (Qtd in Freidman 78). Moreover, in the postcolonial context, C.L. Innes in The Cambridge Introduction to Postcolonial Literatures in English (2007) considers the use of the self-referential mode as a tool by postcolonial writers to represent his/her culture and also to capture and address contemporary concerns. Against this backdrop, this paper seeks to explore the use of the self-referential mode by the Nigerian writer Buchi Emecheta in her autobiographical novel Second-Class Citizen (1974).
\end{abstract}

Keywords: Life Writing, Autobiographical Novel, Postcolonial, Women writing.

This open-access work is licensed under a Creative Commons Attribution Noncommercial 4.0 International License. For more information visit https://creativecommons.org/licenses/by-nc/4.0/ 


\section{Introduction}

Second-Class Citizen (1974) is an autobiographical novel by Buchi Emecheta. This novel, together with In the Ditch (1972), another autobiographical novel by the author, was jointly republished as Adah's Story in 1983. Born and bred in Nigerian soil, nurtured with Igbo customs and traditions, the novel portrays the protagonist Adah's protests against cultural assumptions which constrict her and check her quest for selfhood and also explores the transformation which occurs in her life and the way in which the immigrant experience shapes her identity. As an autobiographical novel, The Second-Class Citizen reflects upon Emecheta's own life in England as an émigré through a constructed alternative self. The text engages with the question of individual self-assertion in cultural, ideological and historical contexts. As a woman writer from Nigeria, her work is intensely linked up with the issues concerning women writers of Nigeria. Ideological conflicts over women's roles in society restricted their access to writing and publishing. Consequently, the women writers had to overcome many challenges while confronting, contesting, and creating a new place for themselves. Second-Class Citizen details some of the difficulties the author met within her own home while venturing to write a novel. As Second-Class Citizen is an autobiographical novel about writing a novel, writing in Second-Class Citizen can be seen as a strategy, a form of personal resistance to the dominant discourse about women's writing. Just as writing can be seen as a strategy, the writing of an autobiographical novel can also be seen as a strategic manoeuvre for asserting selfhood. The author sets her goal for self-definition through the medium of writing an autobiographical novel; she re-casts herself out of the only reality she could claim: her experience and the need to survive. As an emigrant writer's autobiographical work, the text also affirms a rejection of whiteimposed denigration of the black self and, makes assertions of a new identity. While regarding 
this autobiographical text of Emecheta, the issue of gender and the value placed on the individual in the composition and functioning of Igbo societies will be considered.

\section{Autobiography and Autobiographical writings:}

In Reading Autobiography: A Guide for Interpreting Life Narrative (2001), Sidonie Smith and Julia Watson write that in Greek, “'autos' signifies 'self', 'bios', 'life', and 'graphe', 'writing.' Taken together in this order, the words denote 'self life writing' a brief definition of 'autobiography"' (1). Life-writing, according to Sidonie Smith and Julia Watson, is a general term for the writing of diverse kinds that takes life as its subject. Such writing can be biographical, novelistic, historical, or an explicit self-reference to the writer. Life narrative includes many kinds of self-referential writing, including an autobiography. Autobiography is concerned with the inner world of the author, the development of his or her personality and a self-reflection in his or her experience of life. French theorist Philippe Lejeune contends that "we call autobiography the retrospective narrative in prose that someone makes of his own existence when he puts the principal accent upon his life, especially upon the story of his own personality" (Qtd in Smith \& Watson 1). Lejeune entwines a relationship between the reader of an autobiography and its author in an autobiographical pact, which is a contract of identity sealed with the authorial signature. In an autobiography, the narrator and the author converge. An autobiography is different from a novel, although it may share common features with the novel in its use of plot, dialogue, setting, characterization, etc. If an autobiography is a self-referential mode of writing, autobiographical fiction is also a self-referential mode. However, in autobiographical fiction, the character narrating the tale does not have the same name as the author but the work comprises events and characters based on the author's own experience. In autobiographical fiction, the authorial signature and the narrator do not converge. 
Autobiographical fiction or novel is understood to be partially fiction where the events narrated may bear a close resemblance to the ground of the narrator's lived experience. However, considering that all fiction may be autobiographical in some way as all fiction may contain elements of the author's own experience, and autobiographies may also sometimes take recourse to fiction while seeming to narrate life stories; a fixed boundary between the autobiographical novel and the non-autobiographical novel is difficult to determine. Moreover, although some autobiographical claims are verifiable such as the place or date of birth, reference to concrete places and well-known events, several others like dreams, myths, images etc., are not verifiable. The presence of an actual autobiography by the same writer helps in tracing the events narrated in autobiographical novels as a characteristic of its writer. In "African Women Writers: Towards a Literary History" Carole Boyce Davies and Elaine Savory Fido write about autobiography as a structured mode of writing that is related to fiction in the sense that it constructs the self as part of an integrated discourse. The authors suggest that the difference between autobiography and autobiographical writing lies in "a question of the degree to which a piece of writing consciously embraces conventions of fiction as opposed to those of autobiography" (Davies 320). The authors point out that certain writers may deploy greater degrees of fiction in their autobiographical writings especially on account of maintaining a sense of propriety with respect to family matters. However, about Buchi Emecheta, the authors contend that she is an exception (Ibid 320).

As autobiographies, as well as autobiographical novels, can be considered as selfreferential modes of writing, a notion of the terms in which the subject preconceives himself/herself becomes pervasive for understanding autobiographies as well as autobiographical novels. Susan Stanford Friedman, in her essay "Women's Autobiographical Selves: Theory and 
Practice" (1988) opens a critique of a seminal essay by Georges Gusdorf where he states that the cultural precondition for autobiography is a pervasive concept of individualism, a "conscious awareness of the singularity of each individual life" (Qtd in Friedman 72). Friedman argues that the individualistic concept of the autobiographical self that pervades Gusdorf's work raises serious problems for critics who recognise that the "self, self-creation, and self-consciousness are profoundly different for women, minorities, and many non-western peoples" (Friedman 73). While taking into account the differences in socialization in the construction of male and female gender identity, Friedman refers to Regina Blackburn in her "In Search of the Black Female Self" and says that the "black women autobiographers use the genre to redefine "the black female self in black terms from a black perspective"” (Qtd in Freidman 78). Cultural differences, experience, and differences in socialization in the construction of male and female gender identity play an important role in understanding the autobiographical works of writers like Emecheta. It is important also to note that the literary tradition of writing in the English language among writers from Nigeria emerged out of the colonial experience, and real-life experiences counted a great deal towards creating that literature. Writers have constantly drawn from their memory archives to address contemporary concerns. C.L. Innes in The Cambridge Introduction to Postcolonial Literatures in English (2007) considers autobiographical writing a strategy frequently used in postcolonial writing. Innes posits that Postcolonial autobiography is often read differently from autobiographies produced in the metropolitan context. For whereas metropolitan autobiographies are more typically works that seek to explore and assert the writer's individualism, postcolonial autobiographies are often written to portray the author as a representative of his cultural group. (Innes 56) 
Innes' definition highlights the use of the self-referential mode as a tool by postcolonial writers to represent his/her culture and also to capture and address contemporary concerns. As a representative of his/her culture, the cultural perspectives, the community life and society provide the very core of the author's relationship with the culture. As Innes also suggests, rather than seeking to explore and assert the writer's individualism, the postcolonial practice seems to explore the social conception of individualism. What Debra Kelly points out in "Life Writing in the Colonial and Postcolonial Contexts" (2005) is relevant here. She considers women's autobiographical practices and postcolonial autobiographical practices as similar in their exploration of the social conception of individualism and writes that in both categories, "The 'I' does not 'represent' a 'we' but is often a vehicle to explore the relation between the 'I' and that 'we'” (Kelly 35).

In Head Above Water, Emecheta recounts an episode that made her aware of her own individual status in her community. In the essay "What They Told Buchi Emecheta: Oral Subjectivity and the Joys of 'Otherhood"' (1990), Cynthia Ward considers the episode a "version-or inversion-of the moment of self-discovery" (Ward 89). This moment of selfdiscovery occurs for Emecheta not in seclusion but while she is amidst other children of her community. The moment instils in her a sense of belonging to her immediate family, her lineage, her clan, her village and her community. It occurs when Emecheta hears the story of her birth from her aunt—whom she also calls big mother-Nwakwaluzo Ogbueyin. Her big mother assures her that the story was meant especially for her because she was important- "Because I was a significant person in our community at Umuezeokolo Odanta in Ibusa" (Head Above Water 9). What is revealed to the young Emecheta's mind through the story is that despite being a tiny scrap of humanity in her premature birth, despite being a girl in a society where boys were 
preferred, despite the fact that she is new to the village, she is a significant person in the community. Her significance is also marked by her storyteller aunt by breaking off the expensive ivory tusk ornaments that marked her status as "the killer of elephants", 1 just because they terrified little Emecheta ${ }^{2}$ (Head Above Water 8). The story represents Emecheta's cultural significance. And as Ward puts it "She was important not despite but because of the fact that her identity was tied into the matrix of familial, ancestral, clan, and village relationships" (Ward 91). The story never leaves her, forever since she nourishes a dream of becoming a storyteller. In The Methodist Girl's High School, she is punished for dreaming about the stories of her big mother when she should have been paying attention in class. On being questioned, she tells Miss Humble, the English teacher, that she wanted to be a writer and was promptly asked to pray for God's forgiveness because, “"Pride goeth before a fall!'”. She does not ask for God's forgiveness at the chapel as advised but says instead: "'But, dear God, I so wish to be a writer, a story-teller, like our mother Ogbueyin and her friends at home in Ibusa"' (Head Above Water 24). Mother Ogbueyin becomes her role model, her very first inspiration. At one place in her autobiography, she remarks that it is mother Ogbueyin's image that she constantly sees when she looks at the mirror (Head Above Water 6). This very sense of interdependence, community and culture is key to understanding Emecheta's autobiographical work. The novel also documents Emecheta's felt need to write stories-her story in the manner of her big aunt, Nwakuluzo Ogbueyin, the traditional Igbo storyteller.

A storyteller's art remained confined to the community. However, Emecheta aimed to tell the story in the mode of writing. By writing in adherence to the tradition of storytelling, Emecheta brings out the perspectives of women just as women storytellers did in the past. But the mode of narration was changed. 


\section{Second-Class Citizen:}

Second-Class Citizen is an autobiographical novel in which the writer Emecheta acquires a narrative distance and re-casts herself authoritatively in her experience by using a fictional name Adah. In the novel, the author questions norms relating to gender socialisation in both the indigenous and the metropolitan cultures and affirms the rejection of white-imposed denigration of blacks in the metropolitan culture. As a woman writer from Nigeria, Emecheta's work is intensely linked up with the issues concerning women writers of Africa. Despite regional differences, African women writers shared a similar fate and despite having a bulk of the writing, women writers did not receive critical acclaim for their works. In her interview with Adeola James (1990), while despairing over the neglect of critics, Ama Ata Aidoo points out that the question of the women writer's voice being muted has to do with the general position of women in society. What women writers have received is only 'the writer's version of the general neglect and disregard that women in the larger society receive...." (James 11-12). Ideological conflicts over women's roles in society, especially on account of colonialism, restricted their access to writing and publishing. Consequently, the women writers had to overcome many challenges while confronting, contesting, and creating a new place for themselves. Re-assertion of the position held by her and other Nigerian women writers remains at the heart of Emecheta's identity as a writer, her strategy as a writer, and her very being as a writer. Although her very first inspiration came from her big aunt in Ibuza who would mesmerise her in her storytelling sessions, Emecheta was also inspired by Flora Nwapa to write-which she acknowledges in the novel, Second-Class Citizen. Further, Second-Class Citizen details some of the difficulties the author encountered in her own home while venturing to write a novel. 
The general attitude towards women in society becomes clear even at the outset of Second-Class Citizen. It becomes evident in the family's disappointment over the birth of Adah, a girl child, and their total ignorance of her desire for education. While Adah's younger brother is sent to school, Adah is made to help her mother at home. When Adah stealthily joins the school and is found absent at home, the mother is taken to the police station. The treatment to which the policemen subject her mother on suspicion of negligence provides an instance of how women could be forced to submit before male authority. Further, the mother's levirate ${ }^{4}$ marriage following the death of her father is a manifestation of cultural constraint that reduces Adah's status to household help. The traditional norm in Igbo societies ordained that a family must have a father or a senior male member as the head. In the absence of a father, individuals within the family are considered homeless. Emecheta writes about her own experience in her autobiography. She writes, "As a child, I was brought up thinking that a happy home must be headed by a man...A home without him is incomplete...and all those from such a home should go about with this chip on their shoulders" (Head Above Water 242). Encouraging children to work was not without benefits for the agrarian way of life in pre-colonial Nigeria. Farm work and large polygamous households required as many hands as possible. That is one reason why human resources were considered a sign of wealth in pre-colonial Nigeria. This invocation of her culture finds an echo in Chieka Ifemesia's study titled Traditional Humane Living Among The Igbo (1978) where he contends that the training and disciplining of children was both an individual and a communal responsibility among the Igbo, and as a part of this process, the community taught its children how "to be at once independent of and dependent upon one's family" (Ifemesia 67). Socialisation/interdependence is an indispensable element of Igbo culture. Ifemesia adds, "In Igbo cosmology, nothing is absolute, everything, everybody, however 
apparently independent, depends upon something, upon somebody else" (Ibid 67). As Ifemesia suggests, the life of the community provides the framework for individual experience in Igbo culture and identities become visible primarily through the individual's active negotiation of her relations to the whole community. Through proper negotiations women, just as men, could rise to positions of authority. Emecheta's "Big Mother" Nwakwaluzo Ogbueyin can be cited as an example. Emecheta writes in her autobiography about the significance of the title 'Ogbueyin' given to her big mother and how she acquired the title: "Although my big mother was a woman, through her strength and achievement she acquired the title Ogbueyin — 'the killer of elephants'." Evidence of her reputation consisted in the ivory bracelets that she wore night and day.

Nevertheless, colonial culture becomes an inescapable reality that soon "hooks them all like opium" as the third-person narrator in Second Class Citizen puts it. It becomes indispensable during Adah's time as is evidenced in the novel. Accomplishment in colonial manners and education is celebrated with much pomp and grandeur in the preparations that the women make to receive a London educated Lawyer. Adah's father uses hushed tones whenever he refers to London. The Lawyer Nweze's arrival and her father's deep reverence for the United Kingdom instil in Adah a deep desire to educate herself and to visit London one day. She nourishes the dream and as the narrator notes, the dream "assumed substance. It lived with her, just like a Presence" (Second Class Citizen 11). With an undaunted spirit, she pursues her dream. Just as she had earlier forced her way into the classroom to secure an education for herself, Adah manipulates her entry into the Methodist Girl's school even at the cost of a hundred and one lash that her uncle gives her. This bold assertiveness of Adah recalls the spirit of Emecheta's "Big Mother" Nwakwaluzo Ogbueyin. While highlighting the natural assertiveness of a child-like Adah, Emecheta also represents the psychology of the girl child who is denied education, who is 
made to remain at home and engage herself in household work merely on account of her gender. Adah feels compelled to rebel to avail the fruits of education. In her autobiography, she narrates two instances that throw light on Adah's mental state. The first instance occurs when the people living in Lagos were preparing to welcome the arrival of the town's first lawyer (The arrival of the lawyer finds a place in the novel Second Class Citizen as already referred to above). Her father's happiness on the occasion reminds Emecheta that her being a girl child had caused her father disappointment. To keep him happy, she makes a vow to herself that she must visit the United Kingdom. That would be her "payment" to her family "for daring to come into this world as a girl" (Head Above Water 27). The second instance Emecheta narrates occurs after her father's death when she realises that her education might stop so that the money could be used for the education of her brother Adolphus. In a fit of anger fuelled by jealousy, she digs her teeth into her brother's back (Head Above Water 14). Determined to further her studies, Adah contrives marriage with Francis, hoping that it would give her the freedom to continue her education and give Francis access to her scholarship money. Ironically, once she gets married, her problems intensify. Nevertheless, Adah plans to bring to fruition the dream of travelling to London—a dream implanted in her by her father who would refer to England as the "holiest of the holies'. When Adah is initially frustrated in her plans to travel abroad, she strategically manoeuvres a change of tactics and decides to be as "cunning as a serpent but as harmless as a dove" (Second Class Citizen 16), a stance that succeeds in enforcing a positive response from her parents-in-law. Adah's troubles, however, take a drastic turn after she follows Francis to London with her three children. The Francis that she meets in London appears strange to Adah. The new Francis Adah meets in London appears to resent Adah's arrival. His behaviour informs her that it is fine for African men to "get civilized in England. But that privilege has not been extended to 
females yet" (Second Class Citizen 34). Francis' personality epitomises a crude admixture of both the Igbo and the English way of life, something, as the novel shows prove disastrous for Adah. Though educated and a working mother in London, Adah has to conform to the traditional duties expected of a wife in Igbo culture. Francis, therefore, does not approve of Adah's lifestyle in London and considers it a mistake to "bring an educated girl to London and let her mix with middle-class English women. They soon knew their rights" (Second Class Citizen 70). Francis seems to be well aware that the 'rights' conflict with the role played by a wife in their society. He chooses to remind her constantly "You keep forgetting that you are a woman and that you are black" (Second Class Citizen 167). While Francis expects Adah to play the role of the traditional Igbo wife in London, he is unable to provide adequately for the family. The second-class status confronted by the black man in a white society 'unmans' or emasculates him and the shame and anger of it is turned on to the woman at home and is manifested in the sexism that Adah experiences at home. Moreover, Christianity also plays a part in according a secondary status to women. Adah reflects: "Those God forsaken missionaries! They had taught Adah all the niceties of life. They had taught her by the Bible that a woman was supposed to be ready to give in to the man at any time...." (Second Class Citizen 30). Both indigenous and imported patriarchy seems to conspire in the subjugation of women. As Emecheta points out in her autobiography, Head Above Water, "woman-still stooped and allowed the culture of her people to enslave her, and then permitted Christianity to tighten the knot of enslavement" (Head Above Water 3). The double bind of tradition and colonial culture takes its toll on the relationship between the husband and wife. Francis refuses to co-operate with Adah by getting a job or by sharing responsibilities of a home simply because he is studying. He expects his well-educated wife to 
work to support him, to continue bearing children and to look after the children as well. Adah reflects:

Francis was from another culture. There was a conflict going on in his head. What was the point of marrying an educated woman? Why had his parents been asked to pay a big price if all she was going to do was to come to England and start modelling her life on that of Englishwomen, not wanting to work, just sitting there doing nothing but washing the babies' nappies? To him, it was being cheated. (174)

In Francis' view, like all Igbo women in their hometown, Adah must find work. Whether he worked or sat idle is of little importance. What mattered was that his parents were asked to pay a huge bride price for her. Such contradictions complicated their lives. When he almost hit her in one instance, Adah is stunned. In her hometown, such an act would not have been possible. Francis would not have been free to act out his frustrations on Adah as his parents would have intervened. The move to London dislocates the values of traditional society and conflict occurs when Francis insists on maintaining the controlling role of a husband as in traditional Igbo society. Adah reflects that if she and Francis had stayed in Nigeria, their life would have been less plagued by troubles. She looks back upon the time when things were smooth at home and she was happy. The third-person narrator informs that "Later, in England, writing about that time of her life almost with nostalgia", Adah "used to ask herself why she had not been content with that sort of life, cushioned by the love of her parents-in-law, spoilt by her servants and respected by Francis's younger sisters" (Second Class Citizen 22). The liminality of her position as an emigrant makes her aware of both the Igbo and the English aspects of culture. Emecheta portrays the in-betweenness of the condition of both husband and wife as individuals pulled in two different directions by values of traditional Igbo culture and those of western culture. Neither 
comfortable in the old culture not fitting into the new culture conflicts. This in-between condition characterised by ambivalence is explained by Bhabha with the metaphor of the stairwell that connects people between two poles belonging neither 'here' nor 'there' (Bhabha 5). Its adverse effect on Francis can be understood in terms of cultural alienation that is analogous to what Jean-Paul Sartre has called "nervous conditions" in the "Preface" to Franz Fanon's The Wretched of the Earth (Fanon 17). Such conditions may cause schizophrenic behaviour in the colonised native. Patrick Colm Hogan writes in the essay "How Sisters Should Behave to Sisters': Women's Culture and Igbo Society in Flora Nwapa's Efuru" that "colonization produces a class of deracinated men who accept neither indigenous custom nor European views but are, in Achebe's phrase, 'no longer at ease' in any culture. This cultural alienation is often viewed as a source of personal cruelty and unscrupulousness" (Hogan 50). This is especially true of Francis who, as instances in the novel show, seems to derive sadistic pleasure in torturing Adah mentally. One example that best exemplifies this trait in Francis is the occasion when Adah was forced to go to her work despite being ill with a child (Second Class Citizen 97).

In the sphere outside the home in London, Adah is first shocked in understanding the fallacy of many of the myths about the people of her dreamland that she had earlier believed. For instance, she believed that the whites never lied. Her father had spoken about London with so much reverence that Adah learnt to associate the name of England as next only to heaven. But when the English 'child-minder' Trudy lies about the children, she discovers "That the whites were just as fallible as everyone else. There were bad whites just as there were bad blacks.... Why then, did they claim to be superior?" (Second Class Citizen 52) Adah's understanding of the whites deepens and she sees that they are "remote, happy in an aloof way, but determined to keep their distance" (Second Class Citizen 39). The more she lives in the English environment, 
the more she realises that "this was a society where nobody is interested in the problems of others" (Second Class Citizen 66). Even suicide attempts were not regarded as a sin, but a way of attracting attention to one's problems. She longs for "the old woman next door who, on hearing an argument going on between a wife and husband, would come in to slap the husband, ... knowing that her words would be respected because she was old and experienced" (Second Class Citizen 66). Adah's observations bring out the stark differences between the communalistic ethos of Nigeria and the individualism inherent in western culture. Negative aspects of western culture such as selfishness, self-centeredness, materialism etc., lead one to ignore other people's concerns as nobody's business, whereas, in the communalistic ethos of Nigeria, everyone is concerned about others of the community. The individual is only a part of the whole; the whole is greater, of more importance. The individualism inherent in Western culture encourages the solitariness of individuals. Adah's encounters with such aspects of western culture shock her and transform her dreamland into a land of problems, poverty, and failures.

Emecheta also depicts the racism that she confronts in London. Adah realises that as a black woman in London, she is discriminated against. Here, black is the 'other'. The extent to which such discrimination is carried becomes evident when the landlady who appears polite over the phone refuses to lend them rooms when she realises that they were blacks. Moreover, Adah and Francis were often confronted by notice boards that said "Sorry, no coloureds." Adah learns that "her colour was something to be ashamed of" (Second Class Citizen 70). The conflict between the two cultures has an impact on the lives of both Adah and Francis. But how each one encounters the conflict differs. While adjusting to the European culture, Adah constantly longs for the communal living and support of an extended Igbo family and Francis longs for the advantages of being a male in Igbo culture. Francis' stubborn pretension of being a traditional 
Igbo man at home combines with the feeling of inferiority on account of his second-class status outside the home and creates problems for Adah. The emasculation suffered by him also makes him violent towards his wife. Adah on the other hand determinedly charts her course of progress. She successfully challenges the repressive sexism meted out by Francis at home as well as the discrimination outside the home on account of her colour. While Francis becomes a victim of racism, Adah persists in considering herself equal to any white. In the absence of the traditional support system that she could have enjoyed in her native land, Adah adopts various strategies to help herself. When all her silent strategies fail, she settles down to writing and that is what causes Francis' antagonism towards her. He is unable to accept Adah in the role of a writer. When Adah tells him about the manuscript of her first novel Francis can only laugh and say, "Whatever was he going to hear next? A woman writer in his own house, in a white man's country?" (Second Class Citizen 178). The conflict between husband and wife comes to a climax when Francis burns the manuscript of the novel The Bride Price-her first attempt at writing. For Adah, the act is equivalent to the killing of a child as she refers to the manuscript as her 'brainchild'. In "African Women Writers: Towards a Literary History" Carole Boyce Davies and Elaine Savory Fido note that problems of the nature that Adah faces have not been uncommon among women writers from Nigeria and also other parts of Africa. Sometimes women writers may be compelled to stop writing because male relatives may consider them as revealing too much about matters considered private (Davies 312 ). The issue is closely related to the struggle that women writers faced in writing and publishing their works. In "Metafiction, Autobiography and Self-Inscription" Mary Modupe Kolawole also writes that "the details may vary but many African women writers have admitted facing similar obstacles and rejection by individuals or publishers" (Kolawole180). Kolawole further adds that to Emecheta, like Adah, "the most 
painful aspect is the rejection by her husband who believes that a black woman's dream of becoming a writer is a false dream" (Kolawole 187). The reason that he cites for burning the manuscript reveals his short-sightedness and narrow-minded vision of African women. A woman writer is envisaged in terms of a social rebel for breaking the propriety of domestic life by writing about it. In "African Women Writers and the African Literary Canon, Carole Boyce Davies and Elaine Savory Fido quote a passage from Emecheta's article "It's Me" where she addresses this problem:

There are many who think I exaggerated in Second Class Citizen, that I distorted reality. But the cruelty with which I was treated by both my husband and by English society is truthfully rendered in the book. Reality appears unbelievable the moment other people see it on paper. My husband wasn't really a bad guy, but he wasn't able to accept an independent woman. (Qtd in Davies 321)

The authors believe that it is the "permanence of putting it on paper" as well as the "protectiveness of a people" towards a culture distorted by Europeans, that causes African women to "shy away from explicit and intimate details of personal oppression" but for Emecheta, "it is the pain involved in telling the story, in re-experiencing it that prompts her writing." The act of writing then becomes a cathartic response (Davies 321).

In Africa Wo/Man Palava: The Nigerian Novel by Women (1996) Chikwenye Okonjo Ogunyemi believes that "Undoubtedly, Adah was treading on dangerous ground by writing. Since writing confers authority on the writer, she was asking for trouble from her insecure husband" (Ogunyemi 238). Francis, an already emasculated Igbo man in London, could not bring himself to accept the position of authority that a writer automatically commands. Francis takes the help of his religious faith just as he does on other occasions to convince Adah of his being 
correct. The burning of the manuscript is purgatorial according to 'Jehovah's witness'. 5 It is meant to cleanse Adah of the sin of transgression. He fails to imagine that out of the ashes of the manuscript may arise a new, militant Adah, determined to have her niche as a writer. To Quote Ogunyemi,

Second-Class Citizen is partially a vendetta against a man who represents Nigerian men's hostile reception of women's writing. When Francis refused to read Adah's manuscript, calling it "rubbish", Emecheta was not only recording a bitter personal experience but was also lamenting the nature of the reception of female work by African men .... (Ogunyemi 239)

Ogunyemi brings out the parallel between Francis' inability to accept Adah in the role of a writer to the general attitude of African men towards women's writing. In a bid to justify her position Adah refers to Flora Nwapa as her precursor: "Well, Flora Nwapa is black and she writes"” (Second Class Citizen 178). Francis, however, replies by burning her manuscript. In recounting her own experience which is also the experience of Adah in Second-Class Citizen, Emecheta says to Adeola James,

The first book I wrote, my husband burnt, and then I found I couldn't write with him around. Again another thing is that if I am writing and someone comes to tell me something disheartening it can upset me...Each time he knew I was involved in writing he would say something that would cripple me mentally for days. So I decided I couldn't get anywhere with a person like that. (James 45)

Francis considers writing as a masculine reserve. Francis makes it clear to Adah that "writing is not meant for women who know nothing other than breastfeed their babies" (SecondClass Citizen 178). By burning her manuscript, Francis attempts to repress Adah's urge to write 
once and for all. The particular act of burning the manuscript culminates in Adah's divorce and triggers Adah's lonely struggle as a single mother with five children in London. Her experiences find a novelistic rendering in Emecheta's first published work In The Ditch.

The immigrant experience shapes Adah's identity, as it does for the author herself, and transforms her as she opens up space and establishes a place for herself in creating a new home away from home. Adah articulates cultural differences, in the 'in-between' spaces that "provide the terrain for elaborating strategies of selfhood.... that initiate new signs of identity and innovative sites of collaboration and contestation..." (Bhabha 02). This site creates space for the artist, young wife and mother to embark on a new journey.

\section{Endnote}

1. Literally "Ogbueyin", the title of Emecheta's big mother translates as "the killer of elephants" (Head 8). The name symbolises her strength and achievement that won her the title "Ogbueyin". The title stands as evidence of the fact that in Igbo societies women could successfully rise above the predetermined social roles of men to build their status. She was Emecheta's big mother and also an ex-hunter.

2. This is incommensurate with the deeply ingrained traditional Igbo belief that 'child is wealth'. Emecheta's aunt retorts to the horrified bystanders: "'When has it ever been a virtue to be rich in wealth and poor in people?"' (Head 9). A child is not only held as a priceless possession but is also considered a communal possession. And as Chieka Ifemesia writes in Traditional Humane Living among the Igbo, the elders "had a duty to comport themselves with such dignity and propriety as to set faultless examples for children and youth" (Ifemesia 58). 
3. Florence Stratton in her book Contemporary African Literature and the Politics of Gender details the problems that African woman writers faced in winning recognition of their works among critical circles. She notes how even after having a good collection of novels and short stories by 1970 , writers such as Flora Nwapa and Bessie Head found no place in works like Gerald Moore's Twelve African Writers, Abdul R. Jan Mohamed's Manichean Aesthetics, Eustance Palmer's The Growth of The African Novel, to name only a few critical works. The lack of critical acclaim leads Ama Ata Aidoo to write with much feeling in her essay "To be an African Woman Writer" that "In fact, the whole question of what attention has been paid or not paid to African writing women is so tragic; sometimes one wonders what desperation keeps us writing". She refers to writing as "one more exclusively male sphere of activity" (Olaniyan 516).

4. Levirate marriage required a widow to marry her husband's brother according to tradition.

5. A denomination of Christianity.

\section{Works Cited}

Achebe, Chinua. "The Writer and His Community". Hopes and Impediments: Selected Essays. Anchor Books, 1988, pp. 48-67.

Aidoo, Ama Ata. "To be an African Woman Writer-an Overview and a Detail." African literature: An Anthology of Criticism and Theory edited by Tejumola Olaniyan \& Ato Quayson, 2007, pp. 514-518.

---, Interview by Adeola James. Adeola James (Ed), In Their Own Voices: African Woman Writers Talk. James Currey, 1990, pp. 9-27.

Bhabha, Homi K. The Locations of Culture. Routledge, 2004. 
Chukwuma, Helen. "Positivism and the Female Crisis". Nigerian Female Writers: A Critical Perspective, edited by Henrietta Otokunafor and Obiagelli Nwodo, Malthouse Press Limited, 1989, pp. 2-18.

Davies, Carole Boyce, and Elaine Savory Fido. “African Women Writers: Towards a Literary History". A History of $20^{\text {th }}$ century African Literatures, edited by Oyekan Owomoyela, University of Nebraska Press, 1993.

Emecheta, Buchi. Head Above Water. Fontana Paperbacks, 1986.

---. Second-Class Citizen. Heinemann, 1974.

---. The Bride Price. George Braziller, 1976

---. The Slave Girl. Heinemann, 1977.

---. The Joys of Motherhood. Heinemann, 1979.

---. "Feminism with a small 'f'." African Literature: An Anthology of Criticism and Theory edited by Tejumola Olaniyan \& Ato Quayson, 2007, pp. 551-57

---. Interview by Adeola James. Adeola James (Ed), In Their Own Voices: African Woman Writers Talk. James Currey, 1990, pp. 35-46.

Fanon, Frantz. The Wretched of the Earth. Penguin Books, 1961.

Finnegan, Ruth. Oral Literature in Africa. Oxford Press, 1970.

Friedman, Susan Stanford. "Women's Autobiographical Selves.” Women, Autobiography, Theory: A Reader, edited by Sidonie Smith \& Julia Watson. The University of Wisconsin Press, 1998.

Head, Dominic. The Cambridge Introduction to Modern British Fiction 1950-2000, Cambridge University Press, 2002. 
Hogan, Patrick Colm. “'How Sisters Should Behave to Sisters': Women's Culture and Igbo Society in Flora Nwapa's Efuru.” English in Africa, vol. 26, no.1, 1999, pp. 45-60.

Ifemesia, Chieka. Traditional Humane Living among the Igbo: An Historical Perspective. Fourth Dimension Publishers, 1978.

Innes, C.L. The Cambridge Introduction to Postcolonial Literatures in English. Cambridge University Press, 2007.

James, Adeola, ed. In Their Own Voices: African Woman Writers Talk. James Currey, 1990.

Kelly, Debra. "Life Writing in the Colonial and Postcolonial Contexts". Autobiography and Independence: Selfhood and Creativity in North African Postcolonial Writing in French. Liverpool University Press, 2005.

Kolawole, Mary Ebun Modupe. "Metafiction, Autobiography and Self-Inscription." Womanism and African Consciousness. Africa World Press, 1997.

Nwapa, Flora "Women and Creative Writing in Africa." African literature: An Anthology of Criticism and Theory edited by Tejumola Olaniyan \& Ato Quayson, 2007, pp. 527-532

Oba, Abdulmumini A. "Juju Oaths in Customary Law Arbitration and Their Legal Validity in Nigerian Courts." Journal of African Law, vol. 52, no. 1, 2008, pp. 139-158

Ogunyemi, Chikwenye Okonjo. Africa Wo/Man Palava: The Nigerian Novel by Women. The University of Chicago Press, 1996.

Olaniyan Tejumola and Ato Quayson, editors. African Literature: An Anthology of Criticism and Theory. Blackwell Publishing Ltd. 2007.

Smith, Sidonie, and Julia Watson. Reading Autobiography: A Guide for Interpreting Life Narrative. Minneapolis: University of Minnesota Press, 2001. 
Smock, Audrey C., and David R. Smock. "Ethnicity and Attitudes Toward Development in Eastern Nigeria." The Journal of Developing Areas, vol. 3, no. 4, 1969, pp. 499-512.

Stratton, Florence. Contemporary African Writing and the Politics of Gender. New York, 1994. Van Allen, Judith. “'Sitting on a Man’: Colonialism and the Lost Political Institutions of Igbo Women." Perspectives on Africa: A Reader in Culture, History and Representation, edited by Roy Richard Grinker, Stephen C. Lubkemann, Christopher B. Steiner, Wiley Blackwell Publishing Ltd., 2010, pp. 399-408.

Ward, Cynthia. "What They Told Buchi Emecheta: Oral Subjectivity and the Joys of 'Otherhood"' PMLA, vol. 105, no. 1, 1990, pp. 83-9.

\section{Bionote:}

Dr Arunima Borah has been serving in the department of English of Jorhat Kendriya Mahavidyalaya for the last 24 years. She is an Associate Professor and is currently heading the Department of English. A post-graduate from North-Eastern Hill University (NEHU), Shillong campus, she completed a Post-graduation Certificate Course in Teaching English (PGCTE) from Central Institute of English and foreign languages (CIEFL), Hyderabad; She has received a doctoral degree $(\mathrm{PhD})$ from Gauhati University. Her areas of specialization are Linguistics, Postcolonial Studies, and Culture studies. She can be reached at arunimajune14@gmail.com

ORCID ID: https://orcid.org/0000-0001-6181-5121

\section{Open Access:}

This article is distributed under the terms of the Attribution-NonCommercial 4.0 International (CC BY-NC 4.0) (https://creativecommons.org/licenses/by/4.0/) which permits any use, reproduction and distribution of the work without further permission provided the original work is attributed as specified on the Transcript: An e-Journal of Literary and Cultural Studies. For more information log on to http://thetranscript.in/

\section{Conflict of Interest Declaration:}

The author declared no potential conflicts of interest about the research, authorship and publication of this article.

(C) Author 